\title{
Quantitative Analysis of a River Basin - A GIS-based Approach
}

\author{
Ketan A.Salunke ${ }^{\mathrm{a}}$, A.S.Wayal \\ ${ }^{a}$ Research Scholar, ${ }^{b}$ Associate Professor \\ ${ }^{\mathbf{a}, \mathbf{b}}$ Department of Civil and Environmental Engineering, Veermata Jijabai Technological Institute,Mumbai- 400019 \\ ${ }^{\mathrm{a}}$ ketan.salunke11@gmail.com, ${ }^{\mathrm{b}}$ aswayal@ vjti.org.in
}

Article History: Received: 10 November 2020; Revised 12 January 2021 Accepted: 27 January 2021; Published online: 5 April 2021

\begin{abstract}
The river basin plays a fundamental role in planning the management of natural resources. The hydrological behavior of the basin depends on the geomorphological parameters of the hydrographic basin. In the present study, a morphometric analysis was performed to determine the linear, areal and relief parameters of the Panzara River, the main tributary of the Tapi River, using the Geographic Information System tool. The river basin is of seventh order, showing a dendritic pattern of drainage that indicates the homogeneity in the texture of the basin. The drainage density in the area is 2.56 and the mean bifurcation ratio 5.065 indicates the less impact of structural deformations on the basin. The stream frequency of the basin is 3.20 showing low relief and high permeability. The present study reveals that the applications of GIS techniques are reliable, take less time and are competent to manage large databases for management of river basins.
\end{abstract}

Keywords: Basin, GIS, Morphometric Analysis, River

\section{Introduction}

The important hydrological unit in any water resource planning is a river basin. A catchment plan is a key aspect in individual water development projects as surface and groundwater sources are depleted day by day due to population growth and rapid urbanization; it becomes a necessity to identify and analyze the geomorphic characteristics and the hydrological aspects of the hydrographic basin. The morphometric analysis of the basins allows a better understanding of the relationships between the various aspects within a hydrographic basin. It also helps in the proper management of the area affected by drought and agricultural factors, which gives an idea of the water table and the demand for water for food production. Basin planning at the micro level is vital for the development of the semi-arid region. Morphometric analysis provides a basis for implementing water management strategies. [2]To describe the relationship between different drainage parameters of the same basin, quantitative morphometric analysis is a suitable method. [1]. The hydrological nature of various basins can be simulated by conducting a correlation study of the morphological and hydrological characteristics of the basin. [12] The analysis of the drainage system and the evaluation of its characteristics can only be understood through the morphometric analysis, as it produce the essential hydrogeological information of the area. Soil erosion assessment is also useful in river basin planning and conservation work [7]. The recent trend in morphometric assessment of drainage using satellite imagery for extracting streams and their associated characteristics is one of the substantial advances in geospatial technology for drainage system mapping and periodic monitoring in the GIS environment. The use of geographic information system (GIS) results into proper understanding of morphology and drainage management if combined with satellite data [10].

In the present study area, various morphometric parameters are analyzed in terms of linear, areal and relief aspect of the basin. All these parameters are helpful to define the strategy for implementation of water resources conservation plan in the watershed. The result obtained in the present study will be utilized as a database for detailed hydrological studies.

\section{Study Area}

The Panzara river is a tributary of river Tapi, located in Northern Maharashtra, India having basin area of about $2972.84 \mathrm{~km}^{2}$ of the north-western part of Deccan plateau. The Panzara basin extends between $20^{\circ}-15^{\prime} \mathrm{N}$ to $21^{\circ}-45^{\prime} \mathrm{N}$ latitude and $73^{\circ}-75^{\prime} \mathrm{E}$ to $76^{\circ}-15^{\prime} \mathrm{E}$ longitude. Administratively it lies in the southern half of Dhule District of Maharashtra State. The Panzara basin is demarcated by the Western Ghats from its West, Galana hills (Eastern off-shoots of Sahyadri) from its south and Kondaibari spur along with east-west dyke range from its north. The source of the river lies in the Shendwad hill in the vicinity of "Mangi-tungi", peaks of extreme northern Sahyadri, The general climate of the area is hot and dry for the whole year except during the monsoon season. The 
maximum temperature is $45^{\circ} \mathrm{C}$ in the summer and minimum $16^{\circ} \mathrm{C}$ in winter season. The normal annual rainfall is range from $500 \mathrm{~mm}$ to $655 \mathrm{~mm}$.

The study area belongs to the Deccan trap from the Cretaceous to the Early Eocene age. There is a development of flat-topped hills and stepped terraces due to the horizontal lava flow pattern. Due to the eruption of the fissure, horizontal basaltic lava flows are deduced. The basalts of the Deccan almost cover the study area. The whole region has numerous embankments and guidelines, which directly influence the distribution and movements of groundwater. The location the Panzara river basin is shown in Figure 1.

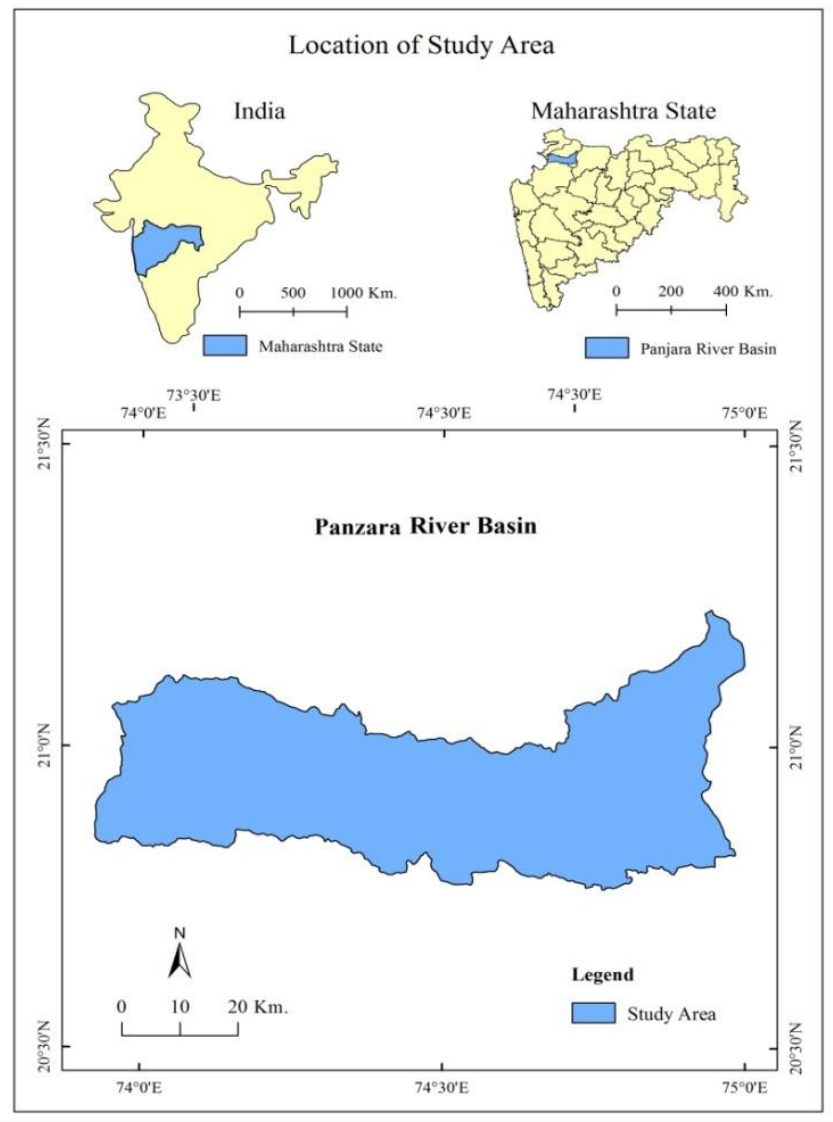

Fig. (a) Location map

\section{Methodology}

The analysis of the morphometric parameters of the Panzara river basin was processed with the aid of topographic maps of the Survey of India (SoI) at a scale of 1: 50000. The base map and the drainage map are prepared for the river basin with the use of topographic maps. The stream network for the basin area traced and scanned. Georeferencing of a scanned stream network map created and converted into digitized format with the help of Arc GIS 10.5. Morphometric analysis performed with Arc GIS 10.5 to find out the parameters of the river basin such as stream order, stream length, basin length, drainage density, stream frequency, texture ratio, bifurcation ratio, form factor, form factor, circularity ratio, constant channel maintenance, constant elongation and compactness ratio etc. The Panzara River Basin Drainage Map as shown in Figure 2 and the Digital Elevation Model for the Panzara Basin as shown in Figure 3.For the delineated basin, morphometric parameters are calculated by formulae suggested by Horton, Strahler, Hadley, Schmun, Miller and Nookratanam as shown in Table I. 
Table I: Formulae to Determine Morphometric parameters

\begin{tabular}{ll}
\hline Parameter & Formula \\
\hline Basin length $\left(\mathrm{L}_{\mathrm{b}}\right)$ & $\mathrm{L}_{\mathrm{b}}=1.3129 \mathrm{~A}^{0.568}$ \\
Drainage Density $\left(\mathrm{D}_{\mathrm{d}}\right)$ & $\mathrm{D}_{\mathrm{d}}=\mathrm{L}_{\mathrm{u}} / \mathrm{A}$ \\
Stream Frequency $\left(\mathrm{F}_{\mathrm{s}}\right)$ & $\mathrm{F}_{\mathrm{s}}=\mathrm{N}_{\mathrm{u}} / \mathrm{A}$ \\
Texture Ratio(T) & $\mathrm{T}=\mathrm{N}_{\mathrm{u}} / \mathrm{P}$ \\
Length of overland & $\mathrm{L}_{\mathrm{o}}=1 /\left(2 \mathrm{D}_{\mathrm{d}}\right)$ \\
flow $\left(\mathrm{L}_{\mathrm{o}}\right) \quad \mathrm{R}_{\mathrm{f}}=\mathrm{A} / \mathrm{L}_{\mathrm{b}}{ }^{2}$ \\
Form Factor $\left(\mathrm{R}_{\mathrm{f}}\right)$ & $\mathrm{R}_{\mathrm{c}}=4 \pi \mathrm{A}^{2}$ \\
Circularity Ratio $\left(\mathrm{R}_{\mathrm{c}}\right)$ & $\mathrm{R}_{\mathrm{e}}=\left(2 / \mathrm{L}_{\mathrm{b}}\right) \times(\mathrm{A} / \pi)^{0.5}$ \\
Elongation ratio $\left(\mathrm{R}_{\mathrm{e}}\right)$ & $\mathrm{C}_{\mathrm{c}}=0.2821 \mathrm{P} / \mathrm{A}^{0.5}$ \\
Compactness Constant $\left(\mathrm{C}_{\mathrm{c}}\right)$ & $\mathrm{R}=\mathrm{H}-\mathrm{h}$ \\
Basin Relief $(\mathrm{R})$ & $\mathrm{R}_{\mathrm{r}}=\mathrm{R} / \mathrm{L}_{\mathrm{b}}$ \\
Relief Ratio $\left(\mathrm{R}_{\mathrm{r}}\right)$ & $\mathrm{R}_{\mathrm{n}}=\mathrm{D}_{\mathrm{d}}{ }^{*}(\mathrm{H} / 1000)$ \\
Ruggedness number $\left(\mathrm{R}_{\mathrm{n}}\right)$ &
\end{tabular}

${ }^{a} \mathrm{Lu}$ total stream length of order $\mathrm{u}$ in kilometer, $\mathrm{Nu}$ total no. of streams of order $\mathrm{u}, \mathrm{A}$ area of the basin $\left(\mathrm{km}^{2} \mathrm{P}\right.$ perimeter $(\mathrm{km}), \mathrm{N}_{\mathrm{u}+1}$ number of streams of the next higher order, $\mathrm{H}$ total relief (relative relief) of the basin in kilometer,)

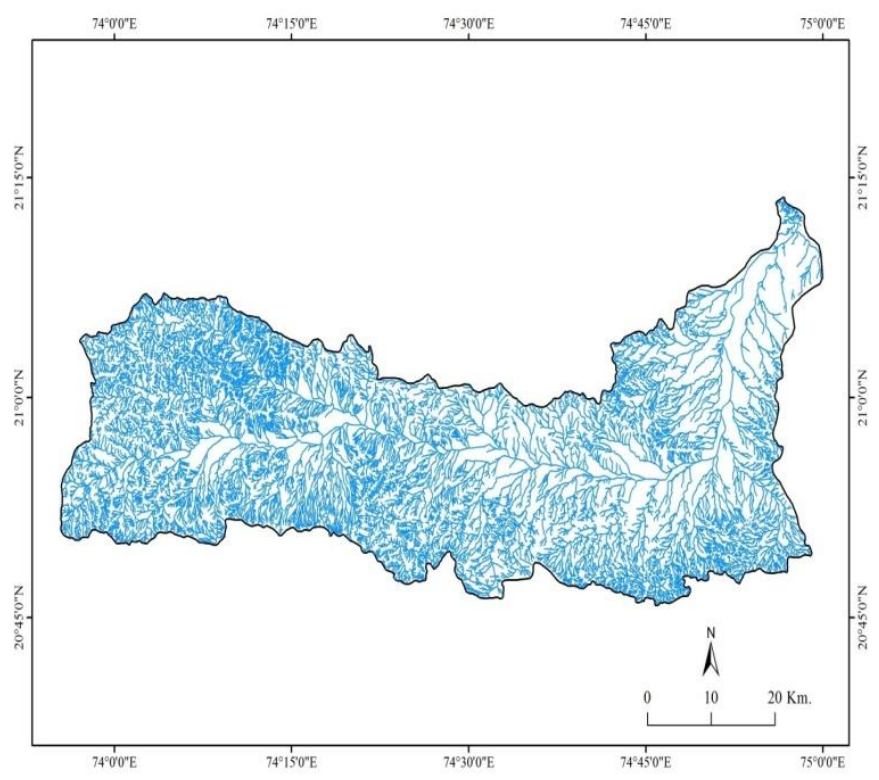

Fig. (b) Drainage map of Panzara basin

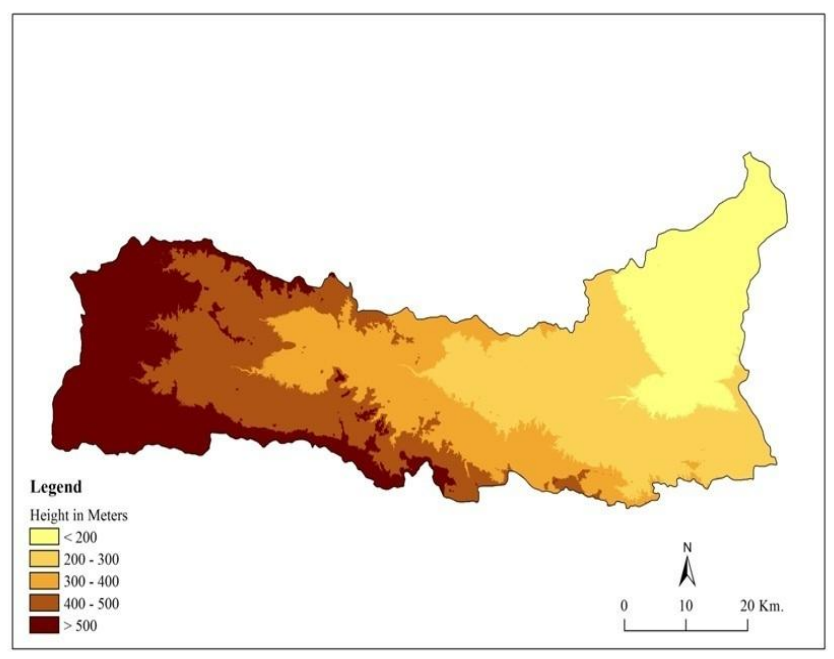

Fig. (c) Digital Elevation Model of Panzara Basin 


\section{Results and Discussion}

The analysis of the morphometric parameters of the catchment area can provide information on the geological and geographical conditions available in the catchment. The drainage map of a basin indicates the availability of water in the basin. The slope of the basin can be calculated with the help of Digital Elevation Model. The nature of basin is defined with combination of morphological parameters with hydrological parameters. The morphometric analysis of the Panzara river basin is carried out using a GIS environment to find linear aspects, areas and surveys, as GIS and remote sensing is helps to understand the design and geomorphological studies of the basin [6]. The total area of the Panzara basin is $2973.11 \mathrm{~km} 2$ and the perimeter is of $373.21 \mathrm{~km}$. The maximum length of the basin is $123.22 \mathrm{~km}$ for the study area. Results of morphometric analysis are discussed below

\section{Stream Order}

Stream order is the ranking of a stream channel segment in a drainage network. According to Strahler's system [7], the smallest un-branched stream with no tributaries is assigned as the $1^{\text {st }}$ order stream. The merging of two 1st order streams forms the $2^{\text {nd }}$ order stream and so on. Analysis shows that Panzara river is of the $7^{\text {th }}$ order basin showing the dendritic pattern.

\section{Stream Number}

In each stream order, a number of stream segments are counted separately and is known as the stream number of that order. If number of streams are less then shows mature topography of a basin while more number of streams indicate youthful topography which is underlying erosion [8]. A graph of a number of streams against stream order plotted and the results obtained shown in Figure 4.Straight line plot indicate that streams of $4^{\text {th }}, 5^{\text {th }}$ and $6^{\text {th }}$ order shows minor variation. Results show that as the stream order increases with decrease in stream numbers. Points are generally close to a straight line with correlation coefficient 0.995 .

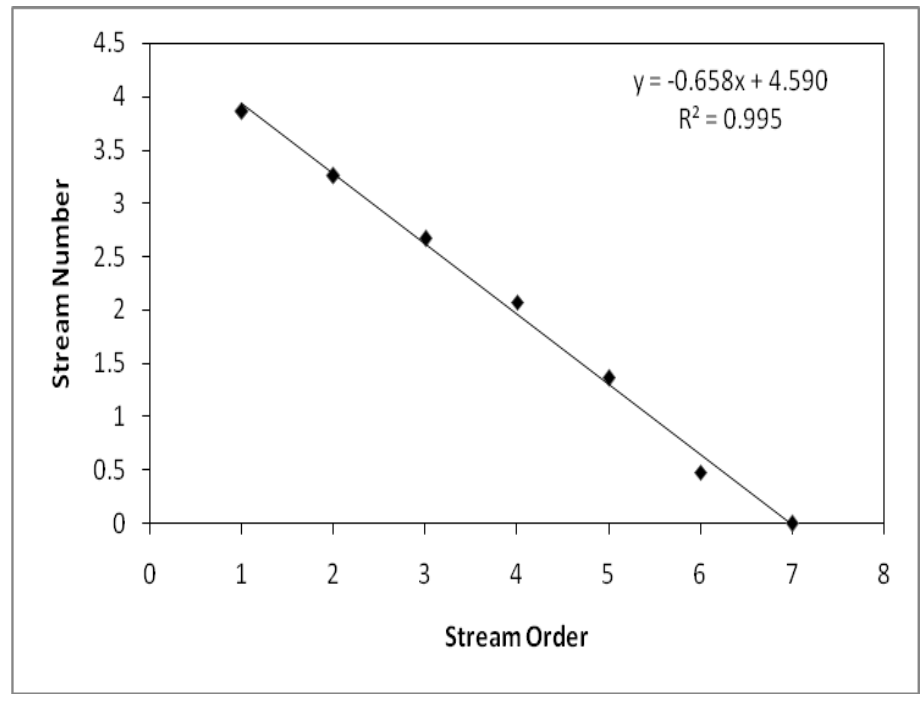

Fig. (d) Stream order and stream number relation.

\section{Stream Length}

The stream length of that order is the total length of the streams in each order [9]. The relationship between the length of the stream and the stream number of its order denotes the mean length of the stream of that order. Generally, stream length and stream order forms inverse relation. Table 2 shows that the mean stream length is less for an order than the next higher order. A graph of stream length against stream order (Figure 5) shows a strong correlation between variables having a coefficient of correlation 0.960 . 


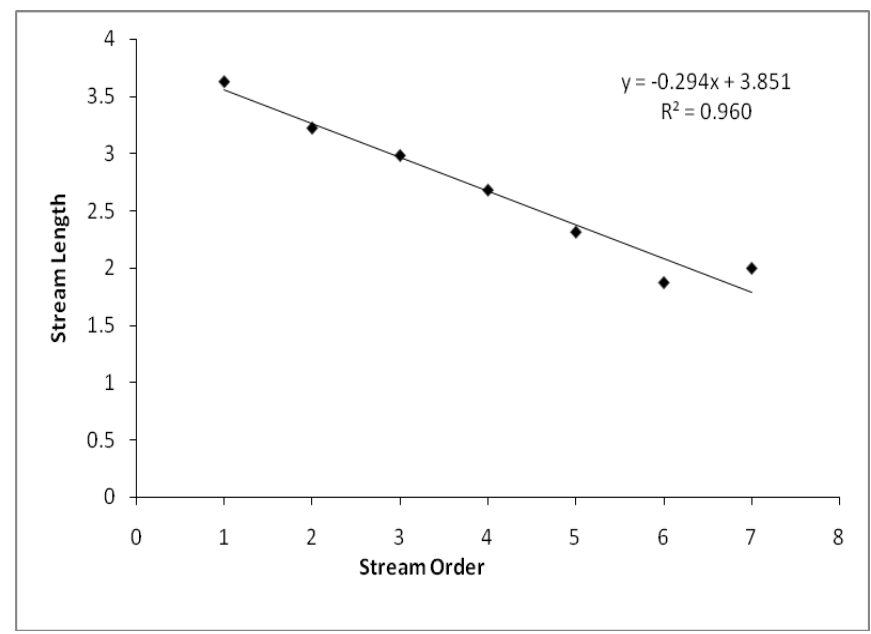

Fig. (e) Stream order and stream length relation

\section{Bifurcation Ratio}

It is a dimensionless parameter which expresses in terms of the ratio of the number of streams of any given order to the number of streams in the next higher order. Generally it lies between 3 and 5 for natural drainage areas and having higher values in case development of elongated narrow basins [10]. The mean bifurcation ratio for a given basin is 4.607 , as shown in Table II. This indicates that structural disturbances are not affecting a drainage pattern of the basin.

Table II Linear aspect of the Panzara basin

\begin{tabular}{llllll}
\hline $\begin{array}{l}\text { Stream } \\
\text { order } \\
(\mathrm{u})\end{array}$ & $\begin{array}{l}\text { No. of } \\
\text { stream } \\
\left(\mathrm{N}_{\mathrm{u}}\right)\end{array}$ & $\begin{array}{l}\text { Stream } \\
\text { length } \\
\left(\mathrm{L}_{\mathrm{u}}\right)\end{array}$ & $\begin{array}{l}\text { Mean } \\
\text { Stream } \\
\left(\mathrm{L}_{\mathrm{m}}\right)\end{array}$ & $\begin{array}{l}\text { Bifurcation } \\
\text { Ratio } \\
\left(\mathrm{R}_{\mathrm{b}}\right)\end{array}$ & $\begin{array}{l}\text { Mean } \\
\left(\mathrm{R}_{\mathrm{b}}\right)\end{array}$ \\
\hline 1 & 7238 & $\begin{array}{l}4247.9 \\
7\end{array}$ & 0.59 & 4.023 & \\
2 & 1799 & 1672.8 & 0.93 & 3.886 & \\
3 & 463 & 965.18 & 2.08 & 3.891 & 4.607 \\
4 & 119 & 481.31 & 4.04 & 5.174 & \\
5 & 23 & 207.09 & 9.00 & 7.667 & \\
6 & 3 & 75.01 & 25 & 3 & \\
7 & 1 & 100.02 & 100.02 & & \\
\hline
\end{tabular}

${ }^{\mathrm{a}} \mathrm{Lu}$ and $\mathrm{L}_{\mathrm{m}}$ are in kilometer.

\section{Drainage Density}

Drainage density of the basin is calculated by finding out average length of streams available in the per unit area of the basin. The drainage density value indicates texture and gives information about streams that how much they are close to each other. In favorable permeable subsoil conditions and dense vegetative cover area, low drainage density occurs. High drainage density occurs in impermeable subsoil conditions and due to lack of vegetation in the basin [11]. Drainage density indicates the relation between climatic conditions, vegetation and erosion of rocks in the area. For the present study value is 2.601 which suggest low drainage density.

\section{Stream Frequency}

It is the ratio of number of stream segments of all order to the area of the basin. If ground is steep then stream frequency is higher which indicate a faster surface runoff as less infiltration. For observed stream frequency value is 3.24 in the present study.

\section{Form Factor}

The ratio of basin area to the square of the maximum length of the basin is known as a form factor. Its value is ranging from 0 to 1 and expresses the shape of the basin. Basins with high form factors indicate more significant maximum flow rates in the short term, while a low value denotes elongated basins. Here form factor value is 0.196 (Table III), which shows an elongated basin. 


\section{Circularity Ratio}

Circularity ratio is calculated by dividing basin area to area of the circle of basin perimeter [12]. Stage of dissection in the study region is indicated by circularity ratio. It is affected by geological nature, climate, land use land cover stream length, stream frequency and slope of the basin [13]. A high value of circularity ratio indicates old stage topography.The circularity ratio (Table III) for the Panzara basin is 0.268.

Table III Areal parameters of the Panzara basin

\begin{tabular}{ll}
\hline Parameter & Value \\
\hline Drainage Density $(\mathrm{km} / \mathrm{km} 2)$ & 2.601 \\
Stream frequency & 3.24 \\
Form factor & 0.196 \\
Circularity ratio & 0.268 \\
Elongation ratio & 0.499 \\
Texture ratio & 25.85 \\
Length of overland flow $(\mathrm{km})$ & 0.192 \\
Compactness Constant & 1.931 \\
\hline
\end{tabular}

\section{Elongation Ratio}

It is calculated by finding the ratio between the diameters of a circle of same area as the drainage basin to maximum length of the basin [14]. As far as runoff is concerned elongated basin is less efficient than the circular basin. Lesser value of ratio denotes more elongation. Elongation ratio calculated (Table III) is 0.499 showing elongated type of basin.

\section{Texture Ratio}

The ratio of a total number of stream segments of all order in basin to perimeter of the basin is texture ratio. Texture ratio (Table III) for the Panzara basin is 25.85 , indicating very fine texture.

\section{Length of overland flow}

It describes the length of the water flow over the surface before it becomes concentrated in defined channels of a stream. It is geographically and hydrologically important in the river basin development. It is calculated as half of the reciprocal of the drainage density. For the study area its value is $0.192 \mathrm{~km}$.

\section{Compactness constant}

The relation among the hydrological basin and that of the circular basin which has the same area as the hydrological basin is expressed by the compactness constant [15]. Increase in basin length results increase in compactness constant. It suggests an elongated basin type nature. For the Panzara basin compactness, constant is 1.931 .

\section{Basin Relief}

The difference in height between the highest and lowest point of the drainage basin gives relief of the basin. It controls the slope of the stream, thus influencing the forms of flooding and the sediment quantity that will be transported. Here basin relief value (Table IV) is $0.912 \mathrm{~km}$.

\section{Relief Ratio}

It is ratio of total relief to a maximum length of the particular basin. It indicates the availability of potential strength to flow water and sediments towards the slope. It is observed that the higher value suggests larger relief and steeper slope. For the Panzara basin (Table 4) relief ratio is 0.0074 .

Table IV Relief parameters of the Panzara basin

\begin{tabular}{ll}
\hline Parameter & Value \\
\hline Basin relief(km) & 0.912 \\
Relief ratio & 0.0074 \\
Relative relief & 0.0024 \\
Ruggedness number & 2.372 \\
\hline
\end{tabular}




\section{Relative Relief}

The ratio of total relief to the perimeter of the basin gives relative relief. It indicates whether the drainage basin is steep or not. It is computed (Table IV) as 0.0024 for the study area.

\section{Ruggedness Number}

Ruggedness number is the multiplication of the total relief and drainage density. It is an indication of the roughness of a basin and structural complexity of the area [16]. For the study area (Table IV), its value is 2.372.

\section{Conclusion}

The Panzara river basin is of $7^{\text {th }}$ order basin as per the analysis, and it shows a dendritic pattern. The analyzed morphometric parameters like area, stream pattern, length, perimeter shows the shape and topography of the river basin. The results of the morphometric analysis provide information related to basin development on priority. The mean bifurcation ratio 4.607 indicates basin has less impact of structural deformations on it. The value of drainage density is 2.601, which shows the area is courser in nature. For the basin form factor is 0.196; elongation ratio is 0.499 , and circularity ratio of 0.268 shows that basin has elongated nature. The stream frequency obtained for the study is 3.24, which show low drainage density. Basin relief value for the basin is $0.912 \mathrm{~km}$ which shows that basin has sufficient slope for a generation of runoff from source to mouth of the basin. The use of the GIS technique provides a more precise analysis of the morphometric parameters than traditional methods which take time. The morphometric analysis of different sub-basins shows a variation of their characteristics related to the hydrological response of the basin. Therefore, the above basin can be divided into sub-basins for a further prioritization study which will generate efficient results for basin development.

\section{References}

PD Aher, J Adinarayana, SD Gorantiwar, "Quantification of morphometric characterization and prioritization for management planning in semi-arid tropics of India: A remote sensing and GIS approach,” J. Hydrol., vol. 511, pp.850-860, Feb 2014.

D Sindhu., Sadashivappa, A.S. Ravikumar, B. L.Shivakumar, "Quantitative Analysis of Catchment Using Remote Sensing and Geographic Information System,” Science direct-aquatic procedia, vol.4, pp.1421-1428, Dec 2015.

S Gajbhiye, SK Mishra, A Pandey, "Prioritizing erosion-prone area through morphometric analysis: R.S. and GIS perspective," J Appl Water Sci.,pp.51-61, Sept 13.

SS Deshmukh , AS Wayal, "Sediment yield estimation using R.S.and GIS upper Karha watershed Maharashtra India,” J. Inst.Eng.India Ser. A, pp. 471-478, Sept 2019.

H.Chandrashekara, KV Lokesh, M Sameena, Jyothi R, G Rangann, "GIS-Based Morphometric Analysis of Two Reservoir Catchments of Arkavati River, Ramanagaram District, Karnataka, "International Conference on Water Resources, Coastal and Ocean Engineering (ICWRCOE 2015) Aquatic Procedia,vol.4, pp.1345 1353, Dec 2015.

SS Deshmukh, AS Wayal, "Groundwater potential of Karha river basin for watershed design," ARPN J.Engg and Appl. Sci.,vol.11,No.23, pp.13556-13559, Dec 2016.

AN Strahler, “Quantitative analysis of watershed geomorphology,”Trans.Am.Geophys Union,vol.38,pp. 913-920, 1957.

Zaidi, K Faisal, "Drainage basin morphometry for identifying zones of artificial recharge: A case study from the Gagas river basin,” J Geol soc India, vol.77, pp.160-166, Feb 2011.

Horton, RE., "Erosional development of streams and their drainage basins: hydrological approach to quantitative morphology,"Geological Society of America Bulletin, vol.56, pp.275-370, March 1945.

AN Strahler, "Quantitative geomorphology of drainage basins and channel networks,"In Te Chow, Ven(Ed).Handbook of applied hydrology. McGraw Hill Book Company, New York 1964.

P Singh, A Gupta, M Singh, "Hydrological inferences from watershed analysis for water resource management using remote sensing and GIS techniques,” Egyp J Remote Sens Space Sci, vol.17, pp.111-121, Dec 2014.

VC Miller, "A quantitative geomorphic study of drainage basin characteristics in the Clinch Mountain area, Virginia and Tennessee," Proj. N.R., Tech Rep. 3, Columbia University, Department of Geology, ONR New York, pp.389-402, 1953.

SA Rahaman, SA Ajeez, S Aruchamy, R Jegankumar., "Prioritization of Sub Watershed Based on Morphometric Characteristics Using Fuzzy Analytical Hierarchy Process and Geographical Information System - A Study of Kallar Watershed, Tamil Nadu,'International Conference On Water Resources, Coastal And Ocean Engineering, Aquatic Procedia, vol. 4,pp.1322 - 1330, Dec 2015.

SA Schumn, "Sinuosity of alluvial rivers in the great plains”Bulletin,Geo.soc.am.,vol.74,pp.1089-1100,1963 
A Javed, MY Khanday, R Ahmed, "Prioritization of Sub-watersheds based on Morphometric and Land Use Analysis using Remote Sensing and GIS Techniques,” J. Indian Soc. Remote Sens, vol.37, pp.261-274, Oct 2009.

G Gopinath, AG Nair, GK Ambili, TV Swetha, "Watershed prioritization based on morphometric analysis coupled with multi-criteria decision making," Arab J Geosci, vol.9, pp.129, Feb 2016.

AF Ayele, Y Hiroshi, Shimizu, Nigussie, Haregeweyn, W Kifle, "Quantitative analysis and implications of drainage morphometry of the Agula watershed in the semi-arid northern Ethiopia," J of Appl Water Sci, vol. 7,pp.3825-3840, Feb 2017.

S Gajbhiye, "Morphometric Analysis of a Shakkar River Catchment Using R.S. and GIS," Int J u- and e-Service, Sci Tech, vol.8, No.2, pp.11-24, Feb 2015.

HG Gundekar, DS Arya, K Goel, "Morphometric Study of Dudhana river basin,” J Hydro ,vol . 34 Isuue 1\& 2, pp. 33-41,2011.

SS Panhalkar, SP Mali, CT Pawar, “ Morphometric analysis and watershed development Hiranyakeshi Basin in Maharashtra, India,” Int J Env Sc., vol 3 No.1,pp.525-534, Jan 2012.

R Kumari, B Sharma, R Singh, RM Singh, RK Tewari, SK Dhyani., "Morphometric and Land Use Analysis of Parasai-Sindh Watershed in Semi-Arid Tropics of Central India," Environment \& Ecology, vol. 33(1),pp. 28-32, March 2015.

K Nookaratnam, Srivastava, YK, V Venkateswarao, E Amminedu, Murthy, KSR, “ Check dam positioning by prioritization of microwatersheds using SYI model and morphometric analysis- remote sensing and GIS perspective," J Indian Soc Remote Sens., vol. 33(1),pp.25-38, March 2005.

PO Osano, "Morphometric characterization and hydrological assessments of River Njoro watershed Using System for Automated Geoscientific Analysis (SAGA) and Shuttle Radar Topographic Mission (SRTM) digital elevation model," Int. J Advan in Remote Sens GIS, vol. 4, No. 1, pp.37-45, Nov2015.

AS Sangle, PL Yannawar, "Morphometric Analysis of Watershed of Sub-drainage of Godavari River in Marathwada, Ambad Region by using Remote Sensing," Int J Comput Appl, vol. 125 (5), pp.30-35, Sept 2015.

RK Somashekar, P Ravikumar, SV Sowmya, A M Dar, AS Ravikumar AS, "Runoff Estimation and Morphometric Analysis for Hesaraghatta Watershed using IRS-1D LISS III FCC satellite data," J Indian Soc Remote Sens ., vol. 39(1),pp.95-106,March 2011.

M Vandana, "Morphometric analysis and watershed prioritization: a case study of Kabani river basin, Waynad district, Kerala, India,” Ind J Geo-Mar Sci., pp.211-222, April 2013.

BN Umrikar. "Morphometric analysis of Andhale watershed, Taluka Mulshi, District Pune, " India.J Appl Water Sci. March 2016 